\title{
PENGARUH EFFECTIVE TAX RATE (ETR) DAN MANAJEMEN LABA TERHADAP COST OF DEBT DAN PROFITABILITY SEBAGAI VARIABEL INTERVENING (Studi Kasus Industri Real Estate and Property Yang Terdaftar Di Bursa Efek Indonesia (BEI) Periode 2014-2018)
}

\author{
Oleh: \\ Hari Purnama \\ FAKULTAS BISNIS UNIVERSITAS PGRI, YOGYAKARTA \\ Email: haripurnama272@gmail.com
}

\begin{abstract}
ABSTRAK
Penelitian ini bertujuan untuk menguji pengaruh Effective Tax Rate, Manajemen laba dan profitabilitas terhadap Cost Of Debt. Untuk menguji pengaruh Effective Tax Rate, dan Manajemen laba terhadap profitabilitas. Untuk menguji pengaruh Effective Tax Rate, dan Manajemen laba terhadap Cost Of Debt yang dimoderasi profitabilitas.

Variabel penelitian ini terdiri dari variabel bebas dan terikat. Variabel bebas penelitian ini adalah Effective Tax Rate, dan Manajemen laba, variabel terikatnya adalah Cost Of Debt dan variabel moderasi profitabilitas. Populasi dalam penelitian ini yaitu seluruh perusahaan sub sektor real estate and property yang berjumlah 48 perusahaan yang terdaftar di Bursa Efek Indonesia (BEI). Teknik Pengambilan Sampel purposive sampling, sehingga sampel yang masuk kriteria sebesar 8 perusahaan. Metode pengambilan data menggunakan dokumentasi. Teknik analisis yang digunakan adalah regresi linier berganda dengan taraf signifikansi $5 \%$.

Effective Tax Rate, Manajemen laba dan profitabilitas secara parsial berpengaruh positif dan signifikan terhadap Cost Of Debt. Effective Tax Rate, secara parsial berpengaruh positif dan signifikan terhadap profitabilitas. Manajemen laba, secara parsial tidak berpengaruh terhadap profitabilitas. profitabilitas tidak mampu memediasi hubungan pengaruh Effective Tax Rate terhadap Cost Of Debt. Profitabilitas tidak mampu memediasi hubungan pengaruh Manajemen Laba terhadap Cost Of Debt.
\end{abstract}

\section{Kata Kunci : Effective Tax Rate, Manajemen Laba, Profitabilitas Dan Cost Of Debt.}

\section{ABSTRACT}

This study aims to examine the effect of Effective Tax Rate, earnings management and profitability on the Cost of Debt. To test the effect of Effective Tax Rate, and earnings management on profitability. To test the effect of Effective Tax Rate, and earnings management on the Cost of Debt moderated by profitability.

This research variable consists of independent and dependent variables. The independent variable of this study is the Effective Tax Rate, and earnings management, the dependent variable is the Cost of Debt and the moderating variable is profitability. The population in this study are all real estate and property sub-sector companies, amounting to 48 companies listed on the Indonesia Stock Exchange (IDX). The sampling technique was purposive sampling, so that the sample that entered the criteria was 8 companies. The data collection method uses documentation. The analysis technique used is multiple linear regression with a significance level of $5 \%$.

Effective Tax Rate, earnings management and profitability are partially positive and significant effect on the Cost of Debt. Effective Tax Rate, partially positive and significant effect on profitability. Earnings management partially has no effect on profitability. profitability is not able to mediate the relationship of the effect of the Effective Tax Rate on the Cost of Debt. Profitability is not able to mediate the relationship between the influence of Earnings Management to the Cost of Debt.

Keywords: Effective Tax Rate, Profit Management, Profitability And Cost Of Debt 


\section{PENDAHULUAN}

Perkembangan kebutuhana manusia akan tempat tinggal semakin meningkat seiring peningkatan jumlah penduduk. Sedangkan lahan untuk tempat tinggal terbatas dan tidak berkembang, hal tersebut menjadikan prospek atau peluang Industri Real Estate and Property. Bisnis di bidang Real Estate and Property membutuhkan modal besar, sehingga perusahaan-perusahaan yang bergerak dibidang Real Estate and Property membutuhkan biaya hutang atau cost of debt yang harus dikelola secara efektif dan efisien. Biaya utang dari suatu perusahaan ditentukan oleh karakteristik perusahaan penerbit utang karena mempengaruhi risiko kebangkrutan, agency cost dan masalah asimetri informasi (Bhoraj dan Sengupta, 2003). Lim (2011) menunjukkan bahwa upaya meminimalkan pajak seperti tax shelters dan Effective Tax Rate adalah pengganti dari penggunaan utang. Perusahaan yang melakukan Effective Tax Rate akan mengurangi penggunaan utang, sehingga akan meningkatkan financial slack, mengurangi biaya dan risiko kebangkrutan, meningkatkan kualitas kredit, dampaknya akan mengurangi biaya utang. Hal ini mendukung trade-off theory bahwa Effective Tax Rate akan mengurangi cost of debt.

Fabozzi, (2007), mendifinisikan cost of debt sebagai tingkat pengembalian yang diinginkan kreditur saat memberikan pendanaan kepada perusahaan. Mengukur cost of debt dihitung dari beban bunga yang dibayarkan oleh perusahaan dalam periode satu tahun dibagi dengan jumlah rata-rata pinjaman jangka panjang dan jangka pendek yang berbunga selama tahun tersebut. Bhoraj and Sengupta, (2003), menunjukkan bahwa cost of debt sebuah perusahaan ditentukan karakteristik perusahaan tersebut, dapat dilihat dari penerbitan obligasi yang mempengaruhi resiko kebangkrutan, agency cost dan masalah informasi asimetri. Salah satu jenis risiko ialah risiko perusahaan, yaitu resiko terkait dengan perusahaan yang menerbitkan suatu sekuritas, misalnya karakteristik dan cara manajemen mengelola perusahaan. Return dan risiko merupakan tradeoff. Maka semakin besar kreditor menilai risiko perusahaan, semakin besar pula bunga yang akan dibebankan kreditor pada perusahaan tersebut.

Upaya perusahaan dalam meminimalkan biaya pajak dapat dilakukan selagi masih dalam ranah peraturan undang-undang yang berlaku, karena pajak merupakan salah satu faktor pengurang laba. Besarnya pajak, seperti kita ketahui tergantung pada besarnya penghasilan. Semakin besar penghasilan, maka semakin tinggi biaya pajak yang dikeluarkan. Dengan demikian maka perusahaan perlu melakukan perencanaan pajak yang dapat mengoptimalakan biaya bajak. (Fadilla Anisa, 2015). Tarif pajak dikatakan efektif apabila nilai yang dihasilkan dari informasi keuangan sesuai dengan harapan perusahaan. Perusahaan berusaha mengalihkan pos-pos yang dapat mengurangi biaya pajak, sesuai pendoman peraturan perpajakan yang masih diperbolehkan (Setiawan Ade, 2016)

Masalah yang sering muncul pada pajak perusahaan adalah perdebatan antara tarif pajak dan tarif pajak efektif. Berdasarkan United States Goverment Accountability Office tarif pajak efektif (effective tax rate/ETR) berbeda dengan tarif pajak yang berlaku. Tarif pajak efektif sebagai ukuran keberhasilan perusahaan dalam melakukan perencanaan pajak. Semakin efektif perencanaan pajak yang dilakukan perusahaan, maka akan meningkatkan laba perusahaan yang akan meningkatkan cost of debt.

Manajemen laba untuk tujuan pajak berusaha meminimalkan pajak terutang yang dibayarkan namun di sisi lain tetap mempertahankan laba optimal untuk memenuhi ekspektasi pemegang saham. Pengelolaan pajak dapat dilakukan secara legal (tax avoidance) maupun illegal (tax evasion). Effective Tax Rate merupakan manipulasi penghasilan secara legal yang masih sesuai dengan ketentuan perundangundangan perpajakan untuk memperkecil jumlah pajak terutang.Tax evasion adalah manipulasi secara illegal untuk memperkecil jumlah pajak terutang.

Hanlon dan Heitzman, (2010) mendefinisikan penghindaran pajak secara luas yaitu pengurangan tarif pajak eksplisit yang merepresentasikan serangkaian strategi perencanaan pajak mulai dari manajemen pajak 
(tax management), perencanaan pajak (tax planning), pajak agresif (tax aggressive), tax evasion, dan tax shelter. Effective Tax Rate yang dilakukan ini dikatakan tidak bertentangan dengan peraturan perundang-undang perpajakan karena dianggap praktik yang berhubungan dengan Effective Tax Rate ini lebih memanfaatkan celah-celah dalam undangundang perpajakan tersebut yang akan mempengaruhi penerimaan negara dari sektor pajak. Pemikiran bahwa pihak manajemen dapat melakukan tindakan yang hanya memberikan keuntungan bagi diri sendiri didasarkan pada satu asumsi yang menyatakan bahwa setiap orang mempunyai perilaku yang mementingkan diri sendiri (Self Interested Behavior). Sehingga terjadinya konflik dalam pengendalian dan pengelolahan perusahaan, sehingga manajer perusahaan melakukan praktik manajemen laba.
Fabozzi, (2007), menjelaskan, bahwa salah satu bentuk penyimpangan yang dilakukan oleh manajemen sebagai agen yaitu dalam proses penyusunan laporan keuangan manajemen dapat memengaruhi tingkat laba yang ditampilkan dalam laporan keuangan atau yang sering disebut dengan manajemen laba (earnings management). Manajemen laba adalah tindakan yang dilakukan manajemen untuk meningkatkan atau menurunkan laba perusahaan dalam laporan keuangan. Tujuan manajemen laba adalah untuk meningkatkan kesejahteraan pihak tertentu walaupun dalam jangka panjang tidak terdapat perbedaan laba kumulatif perusahaan dengan laba yang dapat diidentifikasikan sebagai suatu keuntungan

\section{KAJIAN TEORI DAN PENGEMBANGAN HIPOTESIS}

\section{KAJIAN TEORI}

\section{Biaya Hutang (Cost of Debt)}

Fabozzi, (2007), mendifinisikan cost of debt sebagai tingkat pengembalian yang diinginkan kreditur saat memberikan pendanaan kepada perusahaan. cost of debt dihitung dari beban bunga yang dibayarkan oleh perusahaan dalam periode satu tahun dibagi dengan jumlah rata-rata pinjaman jangka panjang dan jangka pendek yang berbunga selama tahun tersebut. Menurut Fabozzi, (2007), cost of debt, dihitung dari besarnya beban bunga perusahaan dalam satu periode dibagi dengan jumlah rat-rata pinjaman jangka pendek dan jangka panjang yang menghasilkan bunga pinjaman selama tahun. Adapun formulanya sebagai berikut:

\section{Beban Bunga \\ Rata-Rata Hutang jangka Panjang dan Pendek}

\section{Profitabilitas}

Salah satu rasio untuk mengukur profitabilitas adalah Return on Asset (ROA). Rasio ini sering disebut sebagai Return on Asset. Rasio ini mengukur seberapa efektif perusahaan memanfaatkan sumber ekonomi yang ada untuk menciptakan laba. ROA adalah salah satu ratio keuntungan yang menunjukkan kemampuan perusahaan dalam menghasilkan laba dari aktiva yang dipergunakan. ROA positif menunjukkan bahwa modal yang diinvestasikan memberikan keuntungan bagi perusahaan. ROA dapat dirumuskan sebagai berikut:

$$
\text { ROA }=\frac{\text { EAT }}{\text { Total Aktiva }}
$$

\section{Effective Tax Rate}

Menurut Fullerton dalam (Ardiansyah, 2014) average effective tax rate relatif mudah untuk dihitung dan berguna untuk mengukur pendapatan dari pemilik modal, pendapatan pemerintah, dan ukuran sektor publik. Sedangkan marginal effective rate lebih spesifik digunakan untuk menyelidiki dampak yang terjadi atas kegiatan investasi yang dilakukan perusahaan. Cash ETR (cash Effective Tax 
Rate) perusahaan, yaitu kas yang dikeluarkan utuk membayar pajak dibagi dengan laba sebelum pajak. Adapun formulanyya:

$$
\text { Cash ETR }=\frac{\text { Current Tax Expense }}{\text { Pretax Income }}
$$

\section{Pretax Income}

Manajemen Laba

Manajemen laba merupakan aktivitas manajerial untuk "mempengaruhi" laporan keuangan baik dengan cara memanipulasi data atau informasi keuangan perusahaan maupun dengan cara pemilihan metode akuntansi yang diterima dalam prinsip akuntansi berterima umum, yang pada akhirnya bertujuan untuk memperoleh keuntungan perusahaan. (Aditama, 2014). Manajemen laba diukur dengan menggunakan rumus Scaled Earning Changes (penghasilan perubahan berskala) dengan menggunakan rumus sebagai berikut:

Scaled Earning Changes it $=$

\section{Net Income it - Net income i $(t-1)$}

\section{Market Value Equity $i(t-1)$}

Market Value Equity diukur dengan formula yakni

MVE $i(t-1)=$ Saham yang Beredar $\times$ Harga Saham

\section{PENGEMBANGAN HIPOTESIS}

\section{Pengaruh Effective Tax Rate terhadap Cost of} Debt

Menurut (Fatimatuz Zahro, 2018) Effective Tax Rate terbukti menyebabkan cost of debt menjadi besar karena kreditor lebih memandang perilaku perencanaan pajak sebagai tindakan yang mengandung risiko, yaitu risiko sanksi denda dan sanksi pidana hingga kehilangan reputasi yang dapat merugikan perusahaan dalam kelangsungan hidup usahanya. Jika perusahaan lebih berisiko maka kreditur akan menerima pengembalian yang lebih besar untuk menutupi risiko tersebut sehingga biaya hutang akan menjadi lebih tinggi. Menurut penelitian (Puspitasari, 2014) perusahaan yang memiliki laba tinggi akan mengakibatkan beban pajak tinggi. Perusahaan enggan membayar pajak tinggi sehingga perusahaan melakukan penghindaran pajak dengan memanfaatkan biaya bunga dengan menambah hutang mereka. Semakin perusahaan berusaha menghindari pajak maka akan semakin tinggi biaya bunga yang dikeluarkan sehingga akan meningkatkan biaya hutang. Hasil penelitian yang dilakukan oleh (Fatimatuz Zahro, 2018) menemukan bahwa penghindaran pajak yang diukur dengan ETR berpengaruh positif terhadap biaya hutang. Berdasarkan uraian di atas maka hipotesis penelitian adalah:

\section{H1: Effective Tax Rate berpengaruh positif terhadap Cost Of Debt}

Pengaruh Manajemen Laba terhadap Cost of Debt

Manajemen laba merupakan aktivitas manajerial untuk "mempengaruhi" laporan keuangan baik dengan cara memanipulasi data atau informasi keuangan perusahaan maupun dengan cara pemilihan metode akuntansi yang diterima dalam prinsip akuntansi berterima umum, yang pada akhirnya bertujuan untuk memperoleh keuntungan perusahaan. (Aditama, 2014).

Menurut Scott (2012) bahwa manajemen laba adalah pilihan oleh manajer kebijakan akuntansi, atau tindakan nyata yang mempengaruhi pendapatan sehingga dapat mencapai beberapa tujuan laba yang dilaporkan. Jadi manajemen laba dapat dipandang sebagai sebuah estimasi laba agar terhindar dari reaksi negatif para investor, serta dapat digunakan untuk melindungi diri dan perusahaan dalam mengantisipasi kejadian yang tidak terduga atas keuntungan dari pihak yang terlibat didalam kontrak (Wiyadi et al, 2017), Semakin besar kebijakan manajen laba dilakukan, maka akan memperbesar cos of debt perusahaan, sehingga hipotesis yang diajukan adalah sebagai berikut:

Hipotesis 2: Manajemen Laba berpengaruh positif terhadap cost of debt.

\section{Pengaruh Profitabilitas Terhadap Cost Of Debt}

Profitabilitas adalah rasio untuk mengukur besarnya kemampuan suatu perusahaan untuk 
memperoleh keuntungan ditinjau dari kemampuan perusahaan yang bersangkutan dalam memperoleh laba dibanding dengan jumlah aktiva yang dimilikinya. Ardyansah (2014) menyebutkan bahwa hubungan antara profitabilitas dan cost of debt bersifat langsung dan signifikan. Tingkat pendapatan cenderung berbanding lurus dengan biaya hutang, sehingga perusahaan yang mempunyai tingkat keuntungan yang tinggi cenderung memiliki cost of debt yang tinggi. Meningkatnya profitabilitas suatu perusahaan dapat disebabkan oleh meningkatnya kapasitas perusahaan atau sumber pendanaan dalam menjalankan aktivitas bisnis (Frank, et.al., 2014). Hal itu sejalan dengan penelitian Setiawan dan Al-Ahsan (2016), menyebutkan bahwa ada hubungan yang positif antara kemampuan menghasilkan laba perusahaan dengan cost of debt. Berdasarkan uraian tersebut, maka hipotesis yang diajukan dalam penelitian ini adalah sebagai berikut:

Hipotesis 3 : profitabilitas berpengaruh positif terhadap cost of debt

\section{Pengaruh Effective Tax Rate terhadap Profitabilitas}

DeAngelo dan Masulis (2009) menyatakan bahwa perusahaan yang mempunyai utang akan berhubungan negatif dengan non-debt tax shields (seperti pemotongan biaya depresiasi atau investasi kredit pajak). Graham dan Tucker (2006), dan Lim (2011) menunjukkan bahwa kegiatan pajak yang disukai seperti tax shelters dan Effective Tax Rate adalah pengganti dari penggunaan utang. Hal ini mengindikasikan bahwa perusahaan menggunakan utang lebih kecil ketika mereka terlibat dalam perencanaan pajak. Penelitian yang telah diungkapkan diatas menunjukkan bahwa Effective Tax Rate dapat meningkatkan keuntungan perusahaan atau profitabilitas. Nuritomo dan Dwi Martani (2014), menyatakan bahwa perencanaan pajak yang diukur dengan Effective Tax Rate dapat mempenagruhi secara posiif terhadap profitabilitas perusahaan, sehingga hipotesis yang diajukan adalah sebagai berikut:

Hipotesis 4: Effective Tax Rate berpengaruh positif terhadap profitabilitas.

\section{Pengaruh Manajemen Laba terhadap Profitabilitas}

Manajemen laba merupakan aktivitas manajerial untuk "mempengaruhi" laporan keuangan baik dengan cara memanipulasi data atau informasi keuangan perusahaan maupun dengan cara pemilihan metode akuntansi yang diterima dalam prinsip akuntansi berterima umum, yang pada akhirnya bertujuan untuk memperoleh keuntungan perusahaan. (Aditama, 2014). Menurut Scott (2012) bahwa manajemen laba adalah pilihan oleh manajer kebijakan akuntansi, atau tindakan nyata yang mempengaruhi pendapatan sehingga dapat mencapai beberapa tujuan laba yang dilaporkan. Jadi manajemen laba dapat dipandang sebagai sebuah estimasi laba agar terhindar dari reaksi negatif para investor, serta dapat digunakan untuk melindungi diri dan perusahaan dalam mengantisipasi kejadian yang tidak terduga atas keuntungan dari pihak yang terlibat didalam kontrak (Wiyadi et al, 2017), Semakin besar kebijakan manajen laba dilakukan, maka akan memperbesar profitabilitas perusahaan, sehingga hipotesis yang diajukan adalah sebagai berikut:

Hipotesis 5: Manajemen Laba berpengaruh positif terhadap profitabilitas.

\section{Kerangka Pikir Penelitian}

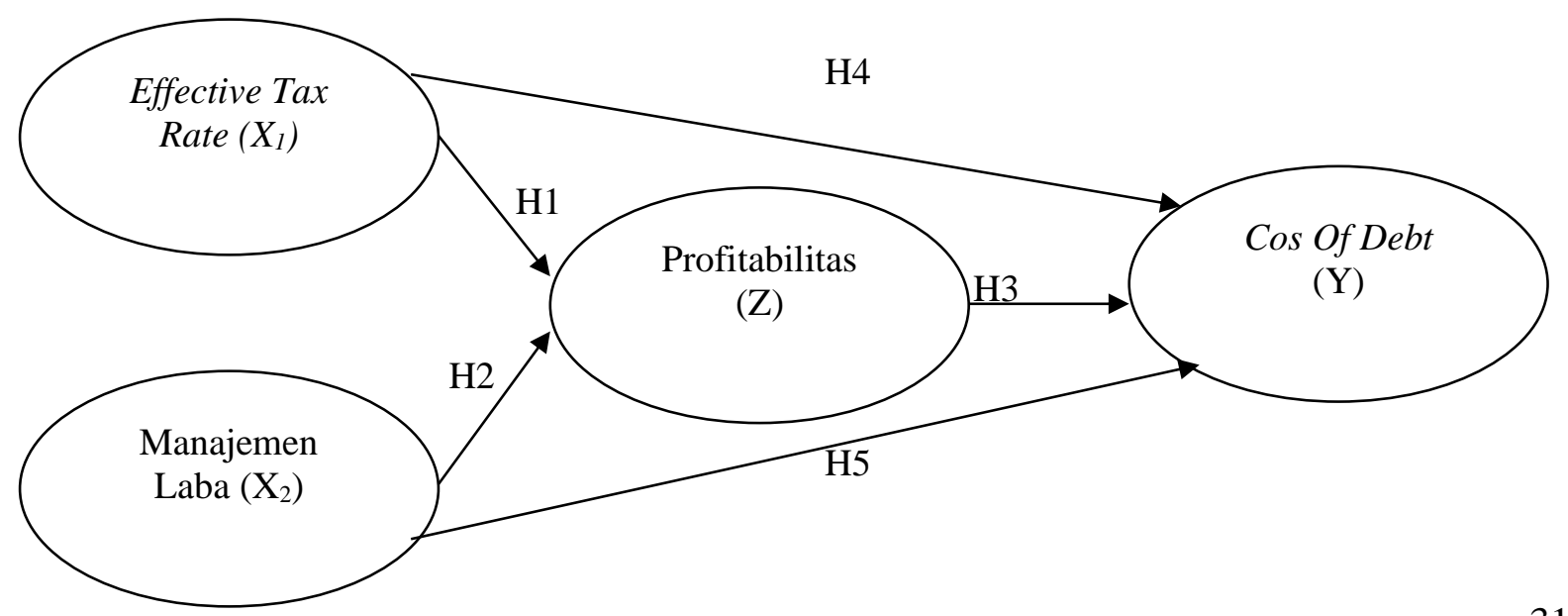




\section{Gambar 1 \\ Kerangka Berpikir}

\section{METODOLOGI PENELITIAN}

Populasi, Sampel dan Teknik Pengambilan Sampel

Populasi dalam penelitian ini adalah keseluruhan dari obyek yang diteliti. Populasi yang digunakan yaitu seluruh perusahaan sub sektor real estate and property yang berjumlah 48 perusahaan yang terdaftar di Bursa Efek Indonesia (BEI). Pengambilan sampel dalam penelitian ini menggunakan metode purposive sampling, yaitu teknik pengambilan sampel secara tidak acak yang menggunakan kriteria tertentu dengan tujuan untuk mendapatkan sampel yang representatif sesuai dengan kriteria:

a. Perusahaan real estate and property yang listed atau terdaftar di Bursa Efek Indonesia (BEI) periode 2014-2018.

b. Perusahaan real estate and property secara continue selalu mempublikasikan dan menyajikan laporan keuangan yang telah diaudit per 31 Desember selama periode pengamatan yaitu 2014-2018.

c. Perusahaan real estate and property tidak mengalami kerugian pada tahun 2014-2018.

\section{Sumber dan Metode Pengumpulan Data}

Dalam memperoleh data yang diperlukan, penulis menggunakan sumber data sekunder yaitu data resume laporan tahunan yang didapat dari website masing-masing perusahaan yang menjadi sampel dalam penelitian ini selama periode pengamatan yaitu 2014-2018. Sedangkan metode pengumpulan data yang dipakai adalah teknik dokumentasi. Teknik dokumentasi yaitu pengumpulan data yang dilakukan dengan melihat data masing-masing perusahaan kemudian mengutip atau menyalin data yang ada dimasing-masing perusahaan yaitu pada perusahaan real estate and property yang bertujuan untuk memperoleh data yang dapat mendukung penelitian dengan mempelajari dan melakukan pendataan.

\section{Teknik Analisis Data}

Teknik analisis data yang digunakan didalam penelitian ini adalah model umum persamaan regresi linier berganda (Multipple Regression Analysis).

\section{HASIL DAN PEMBAHASAN \\ Statistik Deskriptif}

Tabel 1. Statistik Deskriptif

Descriptive Statistics

\begin{tabular}{|l|r|r|r|r|r|}
\hline & $\mathrm{N}$ & Minimum & Maximum & \multicolumn{1}{c|}{ Mean } & Std. Deviation \\
\hline Effective Tax Rate & 40 &, 001 &, 900 &, 19700 &, 193917 \\
Manajemen Laba & 40 &, 008 &, 460 &, 12660 &, 083827 \\
Cost Of Debt & 40 &, 006 &, 331 &, 12528 &, 069238 \\
ROA & 40 &, 002 &, 337 &, 10313 &, 064717 \\
Valid N (listwise) & 40 & & & & \\
\hline
\end{tabular}

Dari seluruh variabel dalam penelitian ini dapat dilihat bahwa seluruhnya memiliki nilai ratarata (mean) yang lebih besar dibandingkan dengan standar deviasi (Std. Deviation). Sehingga dapat disimpulkan bahwa penyebaran data dari seluruh variabel dalam penelitian ini menunjukkan hasil yang normal dan tidak menyebabkan bias

\section{Uji Asumsi Klasik}

Uji Normalitas

Tabel 2. Hasil Uji Normalitas

One-Sample Kolmogorov-Smirnov Test

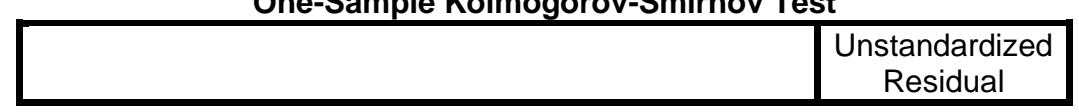




\begin{tabular}{|ll|r|}
\hline N & & 40 \\
Normal Parameters & Mean &, 0000000 \\
Most Extreme Differences &, 04443342 \\
& Std. Deviation &, 146 \\
& Absolute &, 098 \\
& Positive &,- 146 \\
Kolmogorov-Smirnov Z & Negative &, 921 \\
Asymp. Sig. (2-tailed) & &, 364 \\
\hline
\end{tabular}

a. Test distribution is Normal.

b. Calculated from data.

Tabel diatas menunjukkan bahwa nilai Kolmogrov-Smirnov Z sebesar 0,921 dan nilai Asymp. Sig. (2-tailed) sebesar 0,364 yang diperoleh model regresi lebih dari $\alpha(0,05)$ yaitu $0,364>0,05$ yang berarti bahwa data berdistribusi normal.

\section{Uji Multikolinearitas}

Tabel 3. Hasil Uji Multikolinieritas

\begin{tabular}{|ll|r|r|}
\hline Model & & \multicolumn{2}{|c|}{ Collinearity Statistics } \\
\cline { 3 - 4 } & & Tolerance & \multicolumn{1}{c|}{ VIF } \\
\hline 1 & (Constant) & & \\
& Effective Tax Rate &, 857 & 1,167 \\
& Manajemen Laba &, 910 & 1,099 \\
& ROA &, 826 & 1,211 \\
\hline
\end{tabular}

Berdasarkan tabel 3 tidak terjadi masalah multikolinieritas yang timbul. Hal ini ditunjukkan oleh nilai tolerance masing-masing variabel bebas lebih besar dari 0,10 dan nilai Variance Inflation Factor (VIF) masing-masing variabel bebas kurang dari 10, maka dapat disimpulkan bahwa tidak terdapat masalah multikolinearitas.

\section{Uji Heterokedastisitas}

Tabel 4. Hasil Uji Heterokedastisitas

Coefficients $^{\mathrm{a}}$

\begin{tabular}{|c|c|c|c|c|c|}
\hline \multirow[t]{2}{*}{ Model } & \multicolumn{2}{|c|}{$\begin{array}{l}\text { Unstandardized } \\
\text { Coefficients }\end{array}$} & $\begin{array}{l}\text { Standardized } \\
\text { Coefficients }\end{array}$ & & \\
\hline & $B$ & Std. Error & Beta & $\mathrm{t}$ & Sig. \\
\hline 1 (Constant) & ,043 & ,010 & & 4,237 & ,000 \\
\hline Effective Tax Rate & ,063 & ,026 & 391 & 1,429 & ,320 \\
\hline Manajemen Laba &,- 072 & ,058 &,- 194 & $-1,243$ & ,222 \\
\hline ROA &,- 147 & ,079 &,- 306 & $-1,863$ & ,071 \\
\hline
\end{tabular}

a. Dependent Variable: Abs Residual

Dari tabel di atas diperoleh bahwa seluruh variabel bebas mempunyai nilai probabilitas yang lebih besar dari taraf signifikan 0,05, sehingga dapat disimpulkan bahwa dalam model regresi tersebut tidak terjadi Heterokedastisitas.

\section{Uji Autokorelasi}

\section{Tabel 5. Hasil Uji Autokorelasi}

Model Summary ${ }^{b}$

\begin{tabular}{|r|r|r|r|r|r|}
\hline Model & $\mathrm{R}$ & $\begin{array}{c}\mathrm{R} \\
\text { Square }\end{array}$ & $\begin{array}{c}\text { Adjusted } \mathrm{R} \\
\text { Square }\end{array}$ & $\begin{array}{c}\text { Std. Error of } \\
\text { the Estimate }\end{array}$ & Durbin-Watson \\
\hline-1 &, $767^{\mathrm{a}}$ &, 588 &, 554 &, 046248 & 1,986 \\
\hline
\end{tabular}

a. Predictors: (Constant), ROA, Manajemen Laba, Effective Tax Rate

b. Dependent Variable: Cost Of Debt

Berdasarkan tabel diatas diperoleh nilai DW sebesar 1,986. Sedangkan dari tabel DW dengan signifikansi 0,05 dengan jumlah data (n) 40 dan jumlah variabel $\mathrm{k}=2$ menghasilkan nilai $\mathrm{dL}=1,3384$ dan $\mathrm{dU}=1,6589$. Karena nilai DW 1,986 berada diantara dU dan 4-dU maka tidak terjadi autokorelasi. 


\begin{tabular}{|c|c|c|c|c|c|}
\hline \multirow[t]{2}{*}{ Model } & \multicolumn{2}{|c|}{$\begin{array}{c}\text { Unstandardized } \\
\text { Coefficients }\end{array}$} & \multirow{2}{*}{$\begin{array}{c}\begin{array}{c}\text { Standardized } \\
\text { Coefficients }\end{array} \\
\text { Beta }\end{array}$} & \multirow[b]{2}{*}{$t$} & \multirow[b]{2}{*}{ Sig. } \\
\hline & $\mathrm{B}$ & Std. Error & & & \\
\hline (Constant) & ,027 & ,016 & & 1,655 & , 107 \\
\hline Effective Tax Rate & ,149 & 041 & ,418 & 3,616 & ,001 \\
\hline Manajemen Laba & 293 & ,093 & ,355 & 3,163 & ,003 \\
\hline ROA & ,308 &, 126 & ,288 & 2,447 & 019 \\
\hline
\end{tabular}

Dari hasil uji regresi linear berganda pada tabel 6, diketahui pengaruh variabel Effective Tax Rate, Manajemen Laba dan Profitabilitas terhadap variabel dependen yaitu Cost Of Debt maka dapat disusun persamaan regresi linear berganda sebagai berikut:

$\mathbf{Y}=0,027+0,149 \times 1+0,293 X 2+0,308 X 3$

Dari persamaan regresi linear bergada diatas dapat dijelaskan sebagai berikut:

$\mathrm{b}_{0}=0,027$ artinya jika nilai Effective Tax Rate, Manajemen Laba dan profitabilitas sama dengan nol (0), maka Cost Of Debt nilainya sebesar 0,027.

$\mathrm{b}_{1}=0,149$ artinya jika Effective Tax Rate mengalami kenaikan sebesar satu satuan maka Cost Of Debt naik sebesar 0,149 satuan dengan asumsi variabel lain konstan.

$\mathrm{b}_{2}=0,293$ artinya jika Manajemen Laba mengalami kenaikan sebesar satu satuan maka Cost Of Debt meningkat sebesar 0,293 satuan dengan asumsi variabel lain konstan.

$\mathrm{b}_{3}=0,308$ artinya jika profitabilitas mengalami kenaikan sebesar satu satuan maka Cost Of Debt meningkat sebesar 0,308 satuan dengan asumsi variabel lain konstan.

Uji Koefisien Determinasi $\left(\mathbf{R}^{2}\right)$ Persamaan 1

Tabel 7. Hasil Uji Koefisien determinasi $\left(\mathbf{R}^{2}\right)$ Persamaan 1

\begin{tabular}{|c|c|r|c|r|r|}
\hline Model & $\mathrm{R}$ & $\begin{array}{c}\mathrm{R} \\
\text { Square }\end{array}$ & $\begin{array}{c}\text { Adjusted R } \\
\text { Square }\end{array}$ & $\begin{array}{c}\text { Std. Error of the } \\
\text { Estimate }\end{array}$ & Durbin-Watson \\
\hline-1 &, $767^{\mathrm{a}}$ &, 588 &, 554 &, 046248 & 1,986 \\
\hline
\end{tabular}

a. Predictors: (Constant), ROA, Manajemen Laba, Effective Tax Rate

b. Dependent Variable: Cost Of Debt

Dari hasil analisis regresi yang dilakukan diperoleh nilai Adjusted $R$ Square sebesar 0,554 atau 55,4\% yang artinya bahwa pengaruh variabel independen yaitu Effective Tax Rate, Manajemen Laba dan Profitabilitas terhadap Cost Of Debt sebesar 55,4\% sedangkan sisanya sebesar $44,6 \%$ dipengaruhi oleh faktor lain yang tidak masuk dalam model penelitian. Standar Error of Estimate bernilai 0,046248 yang dalam hal ini semakin kecil Standar Error of Estimate akan membuat semakin tepat model regresi memprediksi variabel dependen.

\section{Uji Hipotesis}

Uji Signifikan Simultan (Uji F) persamaan 1

Tabel 8. Hasil Uji Signifikan Simultan (Uji F) persamaan 1

\begin{tabular}{|ll|r|r|r|r|r|}
\hline Model & & Sum of Squares & \multicolumn{1}{|c|}{$\mathrm{df}$} & Mean Square & $\mathrm{F}$ & Sig. \\
\hline 1 & Regression &, 110 & 3 &, 037 & 17,138 &, $000^{\mathrm{a}}$ \\
& Residual &, 077 & 36 &, 002 & & \\
& Total &, 187 & 39 & & & \\
\hline
\end{tabular}

a. Predictors: (Constant), ROA, Manajemen Laba, Effective Tax Rate

b. Dependent Variable: Cost Of Debt

Dari tabel diatas dapat dilihat bahwa nilai signifikansi adalah 0,000. Karena nilai signifikansi lebih kecil dari 0,05 atau 5\%, sehingga dapat disimpulkan bahwa Effective Tax Rate, Manajemen Laba dan profitabilitas secara simultan berpengaruh terhadap Cost Of Debt

Uji Secara Parsial (Uji-t) persamaan 1 
Tabel 9. Hasil Uji Secara Parsial (Uji-t) persamaan 1

\begin{tabular}{|l|r|r|r|r|r|}
\hline \multirow{2}{*}{ Model } & \multicolumn{2}{|c|}{$\begin{array}{c}\text { Unstandardized } \\
\text { Coefficients }\end{array}$} & $\begin{array}{c}\text { Standardized } \\
\text { Coefficients }\end{array}$ & \multicolumn{1}{|c|}{} \\
\cline { 2 - 4 } & \multicolumn{1}{c|}{ B } & Std. Error & \multicolumn{1}{|c|}{ Beta } & t & \multicolumn{1}{c|}{ Sig. } \\
\hline (Constant) &, 027 &, 016 & & 1,655 &, 107 \\
Effective Tax Rate &, 149 &, 041 &, 418 & 3,616 &, 001 \\
Manajemen Laba &, 293 &, 093 &, 355 & 3,163 &, 003 \\
ROA &, 308 &, 126 &, 288 & 2,447 &, 019 \\
\hline
\end{tabular}

Berdasarkan tabel 9 dapat disimpulkan sebagai berikut:

1) Pengujian $\mathrm{H}_{1}$ : Effective Tax Rate berpengaruh positif terhadap Cost Of Debt

Effective Tax Rate memiliki nilai beta 0,149 dan bertanda positif. Nilai signifikansinya sebesar 0,001 lebih kecil dibandingkan dengan 0,05, artinya ada pengaruh antara variabel Effective Tax Rate terhadap Cost Of Debt

Berdasarkan uraian tersebut dapat dikatakan bahwa hipotesis 1 yang berbunyi Effective Tax Rate berpengaruh positif terhadap Cost Of Debt terbukti.

2) Pengujian $\mathrm{H}_{2}$ : Manajemen Laba berpengaruh positif terhadap Cost $\mathrm{Of}$ Debt

Manajemen Laba memiliki nilai beta sebesar 0,293. Nilai signifikansinya sebesar 0,003 lebih kecil dari 0,05. Artinya variabel Manajemen Laba berpengaruh terhadap Cost Of Debt

Berdasarkan uraian tersebut dapat dikatakan bahwa hipotesis 2 yang berbunyi Manajemen Laba berpengaruh positif terhadap Cost Of Debt terbukti.

3) Pengujian $\mathrm{H}_{3}$ : Profitabilitas berpengaruh positif terhadap Cost Of Debt

Profitabilitas memiliki nilai beta sebesar 0,308. Nilai signifikansinya sebesar 0,019 lebih kecil dari 0,05. Artinya variabel profitabilitas berpengaruh terhadap Cost Of Debt

Berdasarkan uraian tersebut dapat dikatakan bahwa hipotesis 3 yang berbunyi profitabilitas berpengaruh positif terhadap Cost Of Debt terbukti.

\section{Sobel Test}

Hasil perhitungan sobel tests dengan menggunakan program sobel test diketahui sebagai gambar berikut:

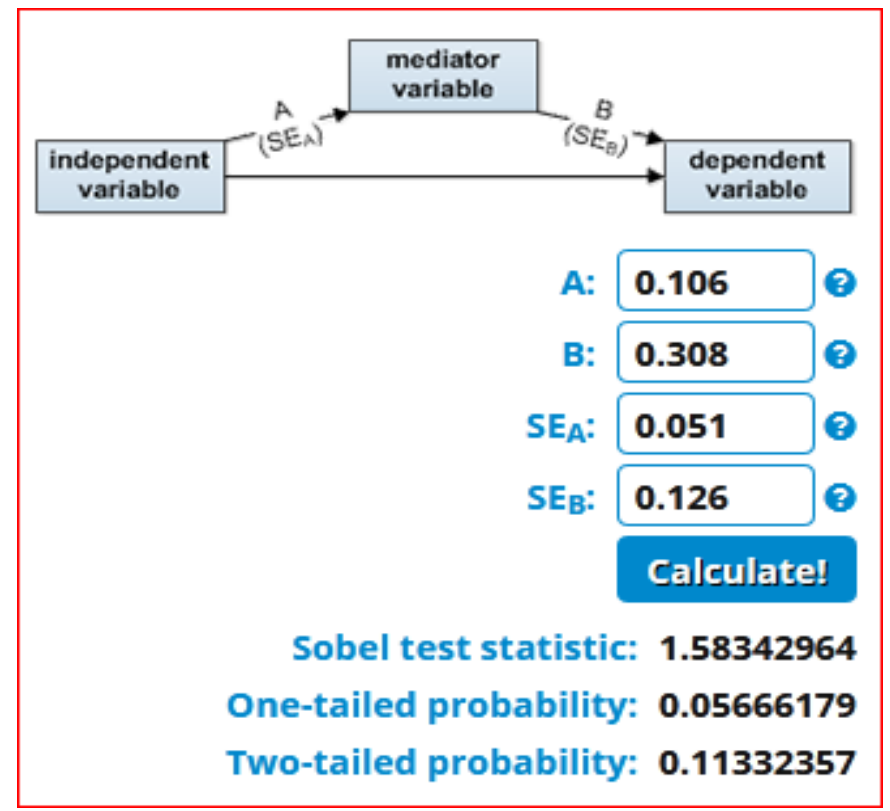

Dari hasil perhitungan sobel test di atas mendapatkan nilai t tabel dengan uji satu sisi sebesar 1,66, sedangkan hasil statistik sobel test sebesar 1,583, one tailed probability sebesar 0,056 , sehingga nilai diperoleh sebesar $1,583<1.66$ dan $(0,566>0,05)$ maka membuktikan 
bahwa profitabilitas tidak mampu memediasi hubungan pengaruh Effective Tax Rate terhadap Cost Of Debt

\section{Persamaan Regresi Berganda II}

\section{$\mathrm{Z}=0,061+0,106 \times 1+0,164 X 2$}

Dari persamaan regresi linear bergada diatas dapat dijelaskan sebagai berikut:

$\mathrm{b}_{0}=0,061$ artinya jika nilai Effective Tax Rate, dan Manajemen Laba sama dengan nol (0), maka profitabilitas nilainya sebesar 0,061 .

$\mathrm{b}_{1}=0,106$ artinya jika Effective Tax Rate mengalami kenaikan sebesar satu satuan maka profitabilitas naik sebesar 0,106 satuan dengan asumsi variabel lain konstan.

$\mathrm{b}_{2}=0,164$ artinya jika Manajemen Laba mengalami kenaikan sebesar satu satuan maka profitabilitas meningkat sebesar 0,164 satuan dengan asumsi variabel lain konstan.

Uji Koefisien Determinasi $\left(\mathbf{R}^{2}\right)$ Persamaan 2

Tabel 10. Hasil Uji Koefisien determinasi $\left(\mathbf{R}^{2}\right)$ Persamaan 2 Model Summary

\begin{tabular}{|c|c|r|r|c|}
\hline Model & $\mathrm{R}$ & $\begin{array}{c}\mathrm{R} \\
\text { Square }\end{array}$ & $\begin{array}{c}\text { Adjusted } \mathrm{R} \\
\text { Square }\end{array}$ & $\begin{array}{c}\text { Std. Error of the } \\
\text { Estimate }\end{array}$ \\
\hline-1 &, $417^{\mathrm{a}}$ &, 174 &, 130 &, 060376 \\
\hline
\end{tabular}

a. Predictors: (Constant), Manajemen Laba, Effective Tax Rate

Dari hasil analisis regresi yang dilakukan diperoleh nilai Adjusted $R$ Square sebesar 0,130 atau $13 \%$ yang artinya bahwa pengaruh variabel independen yaitu Effective Tax Rate, dan Manajemen Laba terhadap Profitabilitas sebesar 13\% sedangkan sisanya sebesar $87 \%$ dipengaruhi oleh faktor lain yang tidak masuk dalam model penelitian. Standar Error of Estimate bernilai 0,060376 yang dalam hal ini semakin kecil Standar Error of Estimate akan membuat semakin tepat model regresi memprediksi variabel dependen.

\section{Uji Hipotesis}

Uji Signifikan Simultan (Uji F) persamaan 2

Tabel 11. Hasil Uji Signifikan Simultan (Uji F) persamaan 2

\begin{tabular}{|c|c|c|c|c|c|c|}
\hline \multicolumn{7}{|c|}{ ANOVA $^{b}$} \\
\hline & & Sum of Squares & $\mathrm{df}$ & Mean Square & $\bar{F}$ & Sig. \\
\hline \multirow[t]{3}{*}{1} & Regression & ,028 & 2 & \multirow{3}{*}{$\begin{array}{l}\text {,014 } \\
\text {,004 }\end{array}$} & \multirow[t]{3}{*}{3,904} & \multirow[t]{3}{*}{, $029^{a}$} \\
\hline & Residual & ,135 & 37 & & & \\
\hline & Total & , 163 & 39 & & & \\
\hline
\end{tabular}

a. Predictors: (Constant), Manajemen Laba, Effective Tax Rate

b. Dependent Variable: ROA

Dari tabel diatas dapat dilihat bahwa nilai signifikansi adalah 0,000. Karena nilai signifikansi lebih kecil dari 0,05 atau 5\%, sehingga dapat disimpulkan bahwa Effective Tax Rate, dan Manajemen Laba secara simultan berpengaruh terhadap profitabilitas

Uji Secara Parsial (Uji-t) persamaan 2

Tabel 12. Hasil Uji Secara Parsial (Uji-t) persamaan 2

Coefficients $^{a}$

\begin{tabular}{|c|c|c|c|c|c|}
\hline \multirow[t]{2}{*}{ Model } & \multicolumn{2}{|c|}{$\begin{array}{l}\text { Unstandardized } \\
\text { Coefficients }\end{array}$} & \multirow{2}{*}{$\begin{array}{c}\begin{array}{c}\text { Standardized } \\
\text { Coefficients }\end{array} \\
\text { Beta }\end{array}$} & \multirow[b]{2}{*}{$t$} & \multirow[b]{2}{*}{ Sig. } \\
\hline & $\mathrm{B}$ & Std. Error & & & \\
\hline (Constant) & ,061 &, 019 & & 3,270 & ,002 \\
\hline Effective Tax Rate & , 106 & 051 & 318 & 2,083 & ,044 \\
\hline Manajemen Laba & ,164 & ,118 & ,213 & 1,394 & , 172 \\
\hline
\end{tabular}

a. Dependent Variable: ROA 
Berdasarkan tabel 12 dapat disimpulkan sebagai berikut:

1) Pengujian H4: Effective Tax Rate berpengaruh positif terhadap profitabilitas

Effective Tax Rate memiliki nilai beta 0,106 dan bertanda positif. Nilai signifikansinya sebesar 0,044 lebih kecil dibandingkan dengan 0,05, artinya ada pengaruh antara variabel Effective Tax Rate terhadap profitabilitas

Berdasarkan uraian tersebut dapat dikatakan bahwa hipotesis 4 yang berbunyi Effective Tax Rate berpengaruh positif terhadap profitabilitas terbukti.

2) Pengujian $\mathbf{H}_{5}$ : Manajemen Laba berpengaruh positif terhadap profitabilitas

Manajemen Laba memiliki nilai beta sebesar 0,164. Nilai signifikansinya sebesar 0,172 lebih besar dari 0,05. Artinya variabel Manajemen Laba tidak berpengaruh terhadap profitabilitas

Berdasarkan uraian tersebut dapat dikatakan bahwa hipotesis 5 yang berbunyi Manajemen Laba berpengaruh positif terhadap profitabilitas tidak terbukti.

\section{Sobel Test}

Hasil perhitungan sobel tests dengan menggunakan program sobel test diketahui sebagai gambar berikut:

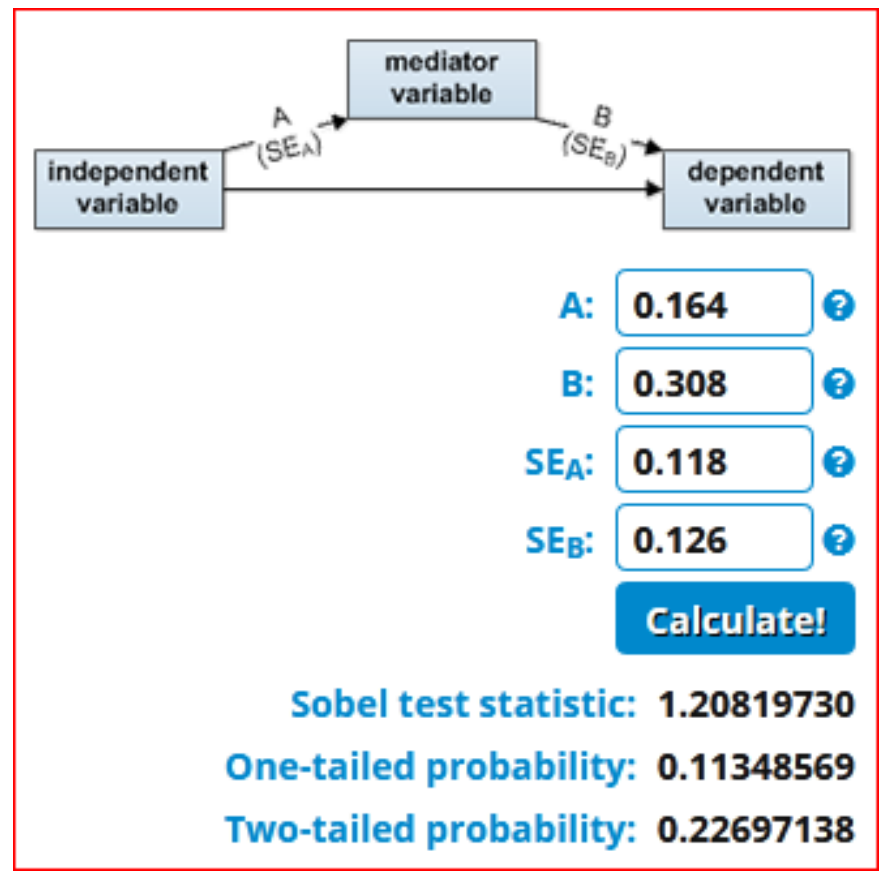

Dari hasil perhitungan sobel test di atas mendapatkan nilai t tabel dengan uji satu sisi sebesar 1,66, sedangkan hasil statistik sobel test sebesar 1,208, one tailed probability sebesar 0,113 , sehingga nilai diperoleh sebesar $1,208<1.66(0,113>0,05)$ maka membuktikan bahwa profitabilitas tidak mampu memediasi hubungan pengaruh manajemen laba terhadap Cost Of Debt

\section{PEMBAHASAN}

Pengaruh Effective Tax Rate terhadap Cost Of Debt

Dari hasil analisis yang telah dilakukan dapat diketahui bahwa variabel Effective Tax Rate berpengaruh positif terhadap Cost of Debt perusahaan Real estate and property yang terdaftar di Bursa Efek Indonesia (BEI) periode 2014-2018. Hal ini senada dengan penelitian yang dilakukan oleh Reylina Purba, Syafi'i, dan
Haryono (2018), yang menyatakan Effective Tax Rate berpengaruh signifikan terhadap Cost Of Debt Pengaruh Effective Tax Rate terhadap Cost Of Debt bersifat positif artinya, setiap kenaikkan Effective Tax Rate maka akan diikuti kenaikkan Cost Of Debt. Hal ini sesuai pendapat Fatimatuz Zahro, (2018) Effective Tax Rate terbukti menyebabkan cost of debt menjadi besar karena kreditor lebih memandang perilaku perencanaan pajak sebagai tindakan yang mengandung risiko, 
yaitu risiko sanksi denda dan sanksi pidana hingga kehilangan reputasi yang dapat merugikan perusahaan dalam kelangsungan hidup usahanya. Jika perusahaan lebih berisiko maka kreditur akan menerima pengembalian yang lebih besar untuk menutupi risiko tersebut sehingga biaya hutang akan menjadi lebih tinggi.

\section{Pengaruh Manajemen Laba terhadap Cost $O f$ Debt}

Dari hasil analisis yang telah dilakukan dapat diketahui bahwa variabel Manajemen Laba secara parsial mempunyai pengaruh terhadap Cost Of Debt industri Real estate and property yang terdaftar di Bursa Efek Indonesia (BEI) periode 2014-2018. Hal ini memiliki hasil yang sama dengan penelitian yang dilakukan oleh Wiyadi et al, (2017), Semakin besar kebijakan manajen laba dilakukan, maka akan memperbesar cos of debt perusahaan. Hal ini sesuai pendapat Scott (2012) bahwa manajemen laba adalah pilihan oleh manajer kebijakan akuntansi, atau tindakan nyata yang mempengaruhi pendapatan sehingga dapat mencapai beberapa tujuan laba yang dilaporkan. Jadi manajemen laba dapat dipandang sebagai sebuah estimasi laba agar terhindar dari reaksi negatif para investor, serta dapat digunakan untuk melindungi diri dan perusahaan dalam mengantisipasi kejadian yang tidak terduga atas keuntungan dari pihak yang terlibat didalam kontrak.

\section{Pengaruh Profitabilitas terhadap Cost Of Debt}

Dari hasil analisis yang telah dilakukan dapat diketahui bahwa variabel profitabilitas secara parsial mempunyai pengaruh terhadap Cost $O f$ Debt industri Real estate and property yang terdaftar di Bursa Efek Indonesia (BEI) periode 2014-2018. Hal ini memiliki hasil yang sama dengan penelitian yang dilakukan oleh Ardyansah (2014) menyebutkan bahwa hubungan antara profitabilitas dan cost of debt bersifat langsung dan signifikan. Tingkat pendapatan cenderung berbanding lurus dengan biaya hutang, sehingga perusahaan yang mempunyai tingkat keuntungan yang tinggi cenderung memiliki cost of debt yang tinggi. Hal ini sesuai pendapat (Frank, et.al., 2014). Meningkatnya profitabilitas suatu perusahaan dapat disebabkan oleh meningkatnya kapasitas perusahaan atau sumber pendanaan dalam menjalankan aktivitas bisnis

\section{Pengaruh Effective Tax Rate terhadap Profitabilitas}

Dari hasil analisis yang telah dilakukan dapat diketahui bahwa variabel Effective Tax Rate berpengaruh positif terhadap Profitabilitas perusahaan Real estate and property yang terdaftar di Bursa Efek Indonesia (BEI) periode 2014-2018. Hal ini senada dengan penelitian yang dilakukan oleh Nuritomo dan Dwi Martani (2014), menyatakan bahwa perencanaan pajak yang diukur dengan Effective Tax Rate dapat mempenagruhi secara posiif terhadap profitabilitas perusahaan. Hal ini sesuai pendapat DeAngelo dan Masulis (2009) menyatakan bahwa perusahaan yang mempunyai utang akan berhubungan negatif dengan nondebt tax shields (seperti pemotongan biaya depresiasi atau investasi kredit pajak). Graham dan Tucker (2006), dan Lim (2011) menunjukkan bahwa kegiatan pajak yang disukai seperti tax shelters dan Effective Tax Rate adalah pengganti dari penggunaan utang. Hal ini mengindikasikan bahwa perusahaan menggunakan utang lebih kecil ketika mereka terlibat dalam perencanaan pajak

\section{Pengaruh Manajemen Laba terhadap Profitabilitas}

Dari hasil analisis yang telah dilakukan dapat diketahui bahwa variabel Manajemen Laba secara parsial mempunyai pengaruh terhadap Profitabilitas industri Real estate and property yang terdaftar di Bursa Efek Indonesia (BEI) periode 2014-2018. Hal ini memiliki hasil yang sama dengan penelitian yang dilakukan oleh Wiyadi et al, (2017), Semakin besar kebijakan manajen laba dilakukan, maka akan memperbesar profitabilitas perusahaan. Hal ini sesuai pendapat Aditama, (2014), Manajemen laba merupakan aktivitas manajerial untuk "mempengaruhi" laporan keuangan baik dengan cara memanipulasi data atau informasi keuangan perusahaan maupun dengan cara pemilihan metode akuntansi yang diterima dalam prinsip akuntansi berterima umum, yang pada akhirnya 
bertujuan untuk memperoleh keuntungan perusahaan.

\section{Pengaruh Effective Tax Rate terhadap Cost Of Debt dengan Moderasi Profitabilitas}

Hasil penelitian menunjukkan bahwa profitabilitas tidak mampu memediasi hubungan pengaruh Effective Tax Rate terhadap Cost Of Debt. Hal ini berarti bahwa semakin tinggi Effective Tax Rate maka akan semakin tinggi Cost Of Debt yang dihasilkan meskipun tanpa dukungan profitabilitas yang tinggi. Pengaruh Effective Tax Rate terhadap Cost Of Debt bersifat positif artinya, setiap kenaikkan Effective Tax Rate maka akan diikuti kenaikkan Cost Of Debt. Jadi profitabilitas tidak mampu mempenagruh secara tidak langusng hubungan antara Effective Tax Rate terhadap Cost Of Debt.

\section{Pengaruh Manajemen Laba terhadap Cost $O f$ Debt dengan Moderasi Profitabilitas}

Hasil penelitian menunjukkan bahwa profitabilitas tidak mampu memediasi hubungan pengaruh Manajemen Laba terhadap Cost Of Debt. Hal ini berarti bahwa semakin tinggi Manajemen Laba maka akan semakin tinggi Cost Of Debt yang dihasilkan meskipun tanpa dukungan profitabilitas yang tinggi. Pengaruh Manajemen Laba terhadap Cost Of Debt bersifat positif artinya, setiap kenaikkan Manajemen Laba maka akan diikuti kenaikkan Cost Of Debt. Jadi profitabilitas tidak mampu mempenagruh secara tidak langusng hubungan antara Manajemen Laba terhadap Cost Of Debt.

\section{PENUTUP \\ KESIMPULAN}

Berdasarkan hasil uji hipotesis dapat disimpulkan bahwa Effective Tax Rate, Manajemen laba dan profitabilitas secara parsial berpengaruh positif dan signifikan terhadap Cost Of Debt. Effective Tax Rate, secara parsial berpengaruh positif dan signifikan terhadap profitabilitas. Manajemen laba, secara parsial tidak berpengaruh terhadap profitabilitas. profitabilitas tidak mampu memediasi hubungan pengaruh Effective Tax Rate terhadap Cost Of Debt. Profitabilitas tidak mampu memediasi hubungan pengaruh Manajemen Laba terhadap Cost Of Debt.

\section{SARAN-SARAN}

Hasil penelitian ini menunjukkan bahwa Effective Tax Rate meningkatkan biaya hutang, sehingga perlunya pihak perusahaan untuk berhati-hati dalam melakukan perencanaan pajak, supaya terhindar dari pengelapan pajak sehingga akan dapat sanksi pada pemeirntah yang pada akhirnya akan meningatkan biaya hutang. Selain itu akan mempengaruhi image negatif investor. Penelitian ini hanya menggunakan perusahaan Real estate and property sebagai sampel sehingga hasil penelitian tidak bisa di generalisir untuk jenis industri yang lain. Periode pengamatan dalam penelitian ini sangat singkat sehingga kurang dapat menangkap volatilitas perilaku tax avoidance. Adanya kelemahan dalam pengukuran cost of debt yang tidak mencerminkan tingkat suku bunga dari kreditur yang sebenarnya karena tidak memperhatikan aspek waktu penarikan pinjaman.

\section{REFERENSI}

Aditama, Ferry. (2014). Pengaruh Perencanaan Pajak terhadap Manajemen Laba pada

Bhojraj, S., \& Sengupta, P. (2003). Effect of corporate governance on bond ratings and yields: The role of institutional investors and outside directors. Journal of Business

Brotodiharjo, R Santoso (2013) Pengantar Ilmu Hukum Pajak, Refika Aditama

Brown, Karen B. (2012). A Comparative Look at Regulation of Corporate Tax Avoidance. New York: Springer.

Chen, S., Chen, X., Cheng, Q., \& Shevlin, T. (2010). Are family firms more tax aggressive than non-family firms?.Journal of Financial Economics 95

Darmawati, D. Khomsiyah dan Rahayu, R.G. (2015) "Hubungan Corporate Governance dan Kinerja Perusahaan". Jurnal Riset Akuntansi Indonesia. Vol. 8, No. 1;

Fabozzi, F.J. (2007). Bond markets, analysis, and strategies (ed.8). New Jearsey: Prentice Hall.

Ghozali, Imam. (2016). Aplikasi Analisis Multivariate dengan Program IBM SPSS. 23. Semarang: BPFE Universitas Diponegoro 
Hanlon, Michelle and Shane Heitzman. (2010). A Review of Tax Research.Journal of Accounting and Economics, Vol 50, pp 127-178. Cost Capital. dalamJournal of Banking and Finance

Herdiyanto, Dedy Ghozim. (2015), "Pengaruh Effective Tax Rate Terhadap Nilai Perusahaan". Skirpsi. Fakultas Ekonomi dan Bisnis, Univesitas Islam Negeri Syarif Hidayatullah, Jakarta.

Lim, YD. (2011). Effective Tax Rate cost of debt and shareholder activism: Evidence from Korea. Journal of Banking \& Finance 35.

Muljono Djoko. 2012. Pengaruh Perpajakan pada Penerapan Standar Akuntansi Keuangan Entitas Tanpa Akuntabilitas Publik. Yogyakarta: Andi

Noviani Aryati Sita (2017), Pengaruh Perencanaan Pajak, Manajemen Laba Dan Good Corporate Governance Terhadap Nilai Perusahaan (Studi Empiris Pada Perusahaan Manufaktur yang Terdaftar di Bursa Efek Indonesia Periode 20122016), Skripsi, Fakultas Ekonomi dan Bisnis, Univesitas Islam Negeri Syarif Hidayatullah, Jakarta.

Pertiwi ,Diah Ayu. (2010) "Analisis Pengaruh Earnings Management terhadap Nilai Perusahaan dengan Peranan Praktik Corporate Governance sebagai Moderating Variabel pada Perusahaan yang Terdaftar di Bursa Efek Indonesia Periode 2005-2008”. Semarang. Universitas Diponegoro.

Sari. D.K. (2010).Ownership Characteristics, Corporate Governance, and Tax Aggressiveness. The 3rd Accounting and The 2ndDotoral Colloquium, Bridging the Gap between Theory, Research and Practice : IFRS Convergence and Application Faculty of Economics Universitas IndonesiaBali-Indonesia

Scott, William R. (2012). "Financial Accounting Theory". Sixth Edition. Canada: Pearson.

Simarmata, Permata. (2014) "Pengaruh Effective Tax Rate Jangka Panjang Terhadap Nilai Perusahaan Dengan Kepemilikan Institusional Sebagai Variabel Pemoderasi (Studi Empiris Pada Perusahaan Manufaktur Yang Terdaftar Di BEI Periode 2011-2012)". Skripsi. Program
Sarjana Fakultas Ekonomika dan Bisnis Universitas Diponegoro, Semarang.

Soemitro Rochmat (2012). Perpajakan Teori dan Teknis Pemungutan . Bandung : Graha Ilmu

Suandy, Erly. (2011). Perencanaan Pajak. Jakarta: Salemba Empat.

Undang-Undang Republik Indonesia Nomor 28 Tahun 2007, tentang Perpajakan.

Zain, Mohammad. 2005. Manajemen Perpajakan. Jakarta: Salemba Empat 